\title{
Undervurderer kreftpasienters plager
}

\section{Obstipasjon, kvalme, depresjon og søvnvansker blant kreftpasienter undervurderes av helsepersonell og nær halvparten av pasientene underbehandles.}

\begin{abstract}
- Symptomene var både vanligere, mer undervurdert og underbehandlet enn vi har trodd. I $10 \%$ av tilfellene underdrev helsepersonell pasientenes plager vesentlig sammenliknet med det pasientene selv rapporterte. $30-50 \%$ av pasientene fikk ikke symptomatisk behandling, som avføringsmidler, kvalmestillende midler, antidepressiver eller sovemedisin selv om symptomene var moderate eller alvorlige. Vi har også funnet at underbehandling har sammenheng med tre hovedfaktorer, nemlig at helsepersonell undervurderer symptomet, at pasienten har lav Karnofsky Performancestatus eller at opioidbehandling nylig er startet, forteller Eivor Alette Laugsand.
\end{abstract}

Hun har undersøkt dette $\mathrm{i}$ to europeiske tverrsnittsstudier med nær 3000 pasienter i hver av studiene. Opioider er førstevalg ved behandling av uttalte smerter hos kreftpasienter, og er en av årsaksfaktorene til mange av symptomene. Utfordringen er at pasienter responderer svært ulikt på opioider. Tidligere forskning har vist at noe av forklaringen på at pasienter trenger ulik opioiddose for å oppnå samme smertelindring, kan skyldes genetisk variasjon, men kun i få studier har man undersøkt sammenhengen mellom genetiske faktorer og de uønskede symptomene. Laugsand fant en sammenheng.

- Kvalme blant kreftpasienter som får opioider er assosiert med genetiske variasjoner $\mathrm{i}$ et serotoninreseptorgen $(H T R 3 B)$, et acetylkolinreseptorgen (CHRM3) og et gen som koder for et enzym i dopaminomsetningen (COMT). Kanskje kan man i fremtiden bruke genetisk informasjon til å skreddersy symptomlindrende behandling, noe som er spesielt viktig for pasienter med langtkommen kreft, sier Laugsand.

\section{Eline Feiring}

eline.feiring@legeforeningen.no

Tidsskriftet

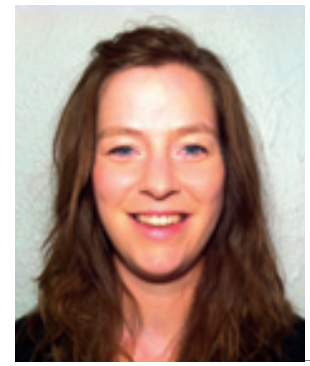

Eivor Alette

Laugsand.

Foto privat

Disputas

Eivor Alette Laugsand disputerte for ph.d.graden ved Norges teknisk-naturvitenskapelige universitet 24.6. 2011 med avhandlingen Symptoms in patients receiving opioids - for cancer pain - clinical and pharmacogenetic aspects.

\section{Rådgiving om spedbarnsernæring i Uganda}

\author{
Råd om fullamming til seks måneders alder hindrer ikke en uheldig \\ vekstutvikling hos barn i løpet av de første to årene i Uganda. Nye tiltak \\ må ta mer hensyn til situasjonen lokalt.
}

Hvert år dør åtte millioner barn før de fyller fem år. Amming regnes som en av de viktigste faktorene for å redusere barnedødeligheten. Det hevdes at tiltak som fremmer fullamming frem til seks måneders alder kan redusere barnedødeligheten med $8 \%$. Helseundervisning er en viktig del av arbeidet. Lars Thore Fadnes har undersøkt situasjonen både hos den generelle befolkningen og blant mødre med hiv i Mbale, Uganda.

- Helsearbeiderne har store utfordringer: Det er mangel på personer, utstyr og lokaler; det gis sjelden oppfriskningskurs, og mange helsearbeidere fører til lite oppdatert informasjon. Den utstrakte fattigdommen gjør det vanskelig å gi barna et godt og variert kosthold. Et annet problem var at retningslinjene som var aktuelle da studiene ble gjennomført, ikke tok nok hensyn til sitasjonen lokalt, de økonomiske faktorene og kulturen, sier Fadnes.
Studiene viste også at hivpositive mødre særlig de med høyest utdanning - ammet kortere enn andre mødre og ofte kun i tre måneder. I lys av senere forskning var dette ammemønsteret lite gunstig. Bruk av mor-til-morrådgivning for å fremme fullamming frem til seks måneders alder hadde ingen positiv effekt på barnas vekst - verken i løpet av de første seks månedene eller ved to års alder.

- Nærmere halvparten av barna til mødrene som fikk mor-til-mor-rådgivning var svært lave for alderen. Til sammenlikning var en tredel av barna til mødrene som ikke fikk mor-til-mor-rådgivning svært lave for alderen. Det er behov for nye tiltak for å fremme bedre ernæring hos spedbarna, sier Fadnes.

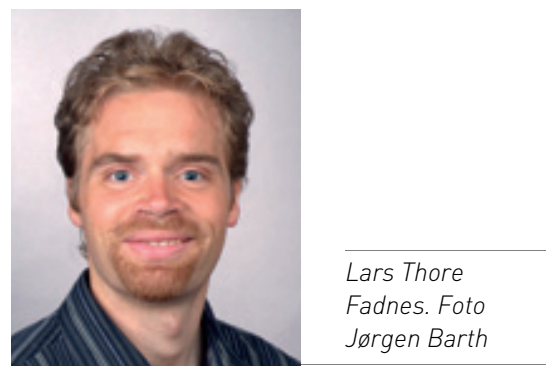

Disputas

Fadnes forsvarte avhandlingen Counselling, child growth and feeding of children in Uganda in the era of HIV: contexts and consequences for ph.d.-raden ved Universitetet i Bergen 3.6. 2011.

\section{Anne Forus}

anneforus@hotmail.com Tidsskriftet 